\title{
DEVELOPMENT STRATEGY OF HUMAN CAPITAL OF PT KIMIA FARMA (PERSERO) TBK
}

\author{
Antoni Ludfi Arifin \\ Institute of STIAMI \\ ludfi@stiami.ac.id
}

\begin{abstract}
This research is a qualitative research with case study at PT Kimia Farma (Persero) Tbk. The purpose of this research is to understand the overall development strategy of human capital of the Company. Data were collected from primary data through interview, observation, and recording; while secodary data were obtained from PT Kimia Farma (Persero) Tbk or from the externals that are used by the researcher to strengthen the premise, theory building, or data from previous researchers. The data collected from primary and secondary sources are then processed. The validity of data is checked though data accuracy checking process (triangulation). This research found that the Company has conducted human reseource development strategy through 1) Integrated HR Development with the Company's visions and missions; 2) open recruitment and selection process will decide and find the candidates who meet the qualifications; 3) preparing assessement center to select the right candidate for the right position; 4) employees training can improve the employees' competence; and 5) the right development of human capital to prepare for the competitiveness in the future.
\end{abstract}

Keywords: Human Capital, Development, Strategy, HR Planning

Pharmaceutical industry in Indonesia, expressed by Sampurno (2007: 200), can not be closed from the competitive situation in Indonesia and globally. To face the increasingly complex landscape of competition, the resources of their nirvana assets must be strengthened.

In addition to physical and capital resources, HR is now an important capital and a source of organizational excellence. In an organization, according to Raza, Anjum, \& Zia (2014: 386) employees are the most valuable asset and a very important resource in business. From planning to implementation of rules and strategy implementation, employees are the core ingredients. As an important and valuable asset, the performance of human resources is an important element in the success and failure of the organization.

Marimuthu, Arokiasamy and Ismail (2009: 266) stated that human capital refers to processes relating to training, education and other professional activities in order to improve the level of knowledge, skills, abilities, values and an employee's social assets that will result in satisfaction and employee performance, and ultimately lead to company performance. Companies need to do a strategy to get 
and retain qualified employees. Without the best strategy, from strategy planning / HR strategy formulation, implementation of HR development strategy, to evaluation of current and executed HR strategy, whether in line between plan and reality; companies will be difficult to compete with other companies.

PT Kimia Farma (Persero) Tbk is an integrated pharmaceutical and healthcare company (healthcare). In running the business from the pharmaceutical business to the healthcare company, the Company has undertaken various transformation and breakthrough efforts by integrating the entire business chain from upstream (raw material and pharmaceutical factory) downstream (Kimia Farma Pharmacy outlet), to excel in business competition. To realize the transformation to the healthcare company in infrastructure, the Company plans to establish raw material facilities, establish health clinics, build hospitals, increase the number of pharmacies; this transformation support is also manifested by preparing the agents of change.

Qualified human resources can be obtained by the Company, since the first recruitment and selection process, both from internal and external sources, to efforts to improve the human resources capacity after becoming a Company employee. However, further to prepare the human resources of the Company requires a mature human resources planning, ensuring the human resource needs in accordance with the business development of the company. Therefore, this research attempts to reveal how PT Kimia Farma (Persero) Tbk plans human resource needs, executes a strategy to gain, maintain and develop its employees so that the Company remains competitive in the competition.

To support the transformation process from the pharmaceutical business to the healthcare company, the company's strategy for its human resources must be comprehensive, from the HR planning process, recruitment \& selection, assessment, to the development of human capital. Yadav \& Dabhade Research (2014: 60) found that establishing an HR planning framework is the organization's primary goal, allowing an organization to ascertain how best to use HR to achieve performance and results.

Koltnerová, Chlpeková, and Samáková (2012: 66) in his research stated that an HR plan must ensure that the right people are in the right job at the right time. They must meet the needs of the company's business objectives. Otherwise, the possible goals and business plan may not be filled. The study of Ekwoaba, Ikeije and Ufoma (2015: 22) to 130 respondents in Fidelity Bank Plc in Lagos Nigeria found that recruitment and selection according to company criteria will affect the performance of the organization where if the criteria of recruitment and selection are more objective then the organization will be more performing . Knapp \& Mujtaba (2011: 154) said employee selection and development is an important activity for HR professionals and managers in today's global economy era. The responsibility of HR management in developing strategies and techniques of human resource selection and development in order to get the best candidates, both 
from internal and external candidates-is through assessment center.

Thornton III \& Gibbons (2009: 183) research explains that assessment centers have been used extensively to assist in the selection of employees in filling in new tasks-such as the application of external selection, internal promotion, early potential identification, and competency certification. Sultana Research (2013: 576) at Square Pharmaceuticals Limited Bangladesh found that training has an important role in the development of employee performance within an organization. Organizations should emphasize competitive training programs for employee and organizational development. The Nda \& Fard study (2013: 91) presents a significant relationship between training and development with employee productivity. In the research found that training and development is an instrument that helps human capital (human capital) in exploring their dexterity. Therefore, training and development are crucial to the productivity of the organization's workforce.

A case study study conducted by Asfaw, Argaw, \& Bayissa (2015: 188) in District Five Administration Office, Addis Ababa, Ethiopia to 100 respondents found that training and development have a positive correlation and statistically have significant relationship between performance and employee effectiveness. The results of this research recommendation states that the District Five Administration Office will be guarded planning the provision of training activities and employee development.

The purpose of this research is to: 1) Review HR strategy planning, recruitment \& selection, and assessment center employees of PT Kimia Farma (Persero) Tbk; 2) Assess training strategy and development of human capital to PT Kimia Farma (Persero) Tbk employees. Focus and sub-focus of the research, 1) How to plan the human resource needs of PT Kimia Farma (Persero) Tbk. 2) What is the strategy of recruitment and selection of prospective employees of PT Kimia Farma (Persero) Tbk. 3) How is the assessment strategy center PT Kimia Farma (Persero) Tbk. 4) How is the training strategy given to the employees of PT Kimia Farma (Persero) Tbk., And 5) How is the strategy of developing human capital of PT Kimia Farma (Persero) Tbk

\section{METHODOLOGY}

This research was conducted at PT Kimia Farma (Persero) Tbk on $\mathrm{Jl}$. Veteran No. 9 Central Jakarta since the beginning of January-September 2016. This research is a qualitative research with case study that tried to explore and answer the problem formulation. In this study, using two data sources, namely primary data and secondary data. Primary data get from direct sources collected by researchers through the process of interviewing and distributing questionnaires to the relevant parties to be included in this study. While secondary data obtained from PT Kimia Farma (Persero) Tbk or sourced from external companies used by researchers to strengthen the rationale, building theory, or data from previous 
researchers relevant to this research.

The author uses the list of questions as data collection materials, through indepth interviews, in the field. Data collected from primary and secondary sources, then processed. Criteria for trustworthiness are 1) Credibility, 2) Transferability 3) Dependability, 4) Confirmability

\section{RESEARCH RESULT}

\section{A. HR Planning Strategy}

In preparing the long term HR development strategy, the Company has developed a roadmap for human capital development from 2013 to 2018. The Company emphasizes five serious concerns in HC development: 1) human resource planning, 2) development Human resources, 3) performance management, 4) remuneration system, and 5) human capital information system (HCIS).

If we look at human resource planning, in 2013 the Company starts to organize adaptive organizational structures on macro and micro situation changes; arrange job description and job specification that more attention to the needs of the organization, and specify job grading in every position. In 2014, as the business unit evolves, with the establishment of a pharmaceutical salt plant, the Company has developed the competency standards of the plant's employees. Likewise in 2015, the Human Capital Division has devised a strategy of preparing prospective international business leaders and developing new businesses (hospitals, for example).

While the Human Capital development roadmap of 2016-2018, the Company began to pay attention to the development of the company's business; by realizing corporate strategy into unit business strategy.

The Company has prepared a roadmap for human resource planning, but from those plans there are several programs that have not been able to be realized well in 2015 and 2016 because the stategic program created by the Company has not been implemented in the year such as, the establishment of hospitals in 2015; and the establishment of Chema Pharmacy Pharmacy in Vietnam and Establishment of PT Kimia Farma Property in 2016.

\section{B. Recruitment and Selection Strategies}

In order to obtain qualified and productive qualified candidates, PT Kimia Farma (Persero) Tbk selects competent and competent staff based on human capital information system (HCIS) and uses valid and reliable tools.

Meeting the needs of employees prioritized from the internal company. However, if from the internal company no one competent, then done external selection including professional hire.

Recruitment and selection programs have been well run, but the most basic thing is to prepare internal human resources who have job competency standards (SKJ) in accordance with vacant positions or positions to be promoted; so that the 
competency gap that occurs is not filled by external candidates (pro-hire). Therefore, the importance of the Company's efforts to prepare internal human resources that have competence in accordance with the HR roadmap that has been prepared.

\section{Strategy Assessment Center}

The purpose of the Company to conduct assessment process is to capture and get the right employees to fill a certain position. Assessment is used to determine the level of competence of employees who have, whether, has been in accordance with the competency standard position (SKJ) / current position competency profile or position to be offered.

From this assessment process will be known level of employee competence. Differences in employee competencies and job competencies-which are held in time or positions to be promoted in the future-this will determine the training and development needs to be provided, to employees, to fit the SKJ / competency profile.

This effort requires an assessment center not only in the form of subdivisions in HC Division of PT Kimia Farma (Persero) Tbk in the physical form of place / space / building; but also the need for procedures, processes, and methods of assessment approaches in the promotion process to find the suitability between the cadidate and the positions to come.

\section{Employee Training Strategy}

The training program prepared by the Human Capital Division of PT Kimia Farma (Persero) Tbk aims to help employees to keep their knowledge and skills up-to-date, prepare career ladder in the future, and ensure employee morale and motivation are well preserved.

With a total of 8,056 employees, either a certain time labor agreement (PKWT) / contract or an indefinite time contract (PKWTT) / permanent employee; which is spread across the whole of Indonesia is a big job of the Human Capital Division in implementing this training program.

Employee training and development programs implemented at PT Kimia Farma (Persero) Tbk refers to competency based training (training based competency). The actual level of competence of each employee is compared to the competencies that should be. Incompatibility between the actual competency level and should (required) will lead to a competency gap. The gap of competence can be overcome by including these employees into training and development programs. Training and development methods applied are through training, assignment, and coaching and mentoring.

\section{E. Human Capital Development Strategy}

The Company's four long-term strategies for developing the Company's 
human resources are: First, to prepare employee resources at the executive level, the Company will establish a pharmaceutical school. Second, the Company also prepares business trainers for corporate university preparation. Third, the Company conducts a coaching culture program, to ensure that corporate values are internalized in the "hearts" of the Company's employees. Fourth, the implementation of E-Learning. With the implementation of E-Learning is expected to reduce educational and training gaps constrained distance and time, so as to maximize the potential employees for the progress of the company.

One important thing to note HC Division PT Kimia Farma is the existence of Law no. 36 years 2014 About Health Workers, who mentioned that the pharmacist's assistant position has changed. This is stated in article 1, paragraph 2, assistant health personnel must have knowledge and / or skills through health education under Diploma III level

\section{DISCUSSION}

\section{A. HR Planning Strategy}

The Company has established and determined the needs of the current number of employees and future needs plans when necessary. Therefore, the Company has prepared a roadmap that is capable of analyzing and planning the current and future human resources needs in accordance with the development of company bisis. This is in line with what Anyadike says, that HR planning is the process of determining and ensuring that the organization will get the right people when it is needed.

Based on this roadmap, the Company has determined the human resource requirements based on the company's business development plan, the plan to manufacture new plants and the addition of new pharmacies. In line with what K. Prashanthi stated (2013: 63) human resources planning is an integral part of business planning, this is in line with what the Company has done in aligning corporate strategy with business unit strategy.

\section{B. Recruitment and Selection Strategies}

The development of the Company's business towards the healtcare company led to the addition of divisions and positions, so it takes recruitment and selection effort that is really able to find candidates who have suitability of competency.

According to Muryanto (2015: 1), Human capital, described by the President Director of PT Kimia Farma (Persero) Tbk-Rusdi Rosman-as one of the important corporate assets. Management The Company wants human capital or human resources that it recruits into assets not liability (burden) for the company. To that end, the process of selecting the company's HR becomes the key to the success of the company's management in developing its business.

The process of selecting human resources, which is meant by Rusdi 
Rosman, is the process of recruitment and selection. A selective process that can filter and get superior seeds that can contribute to the development of the company. This is in line with Noe's opinion, et. al. (2010: 210), that recruitment aims to gain potential employees.

\section{Strategy Assessment Center}

The Company realizes that human resource development is fundamental to be done in order for the sustainability of the company's business to run. The business development of this company must be in line with the development of company's human resources. Three things to consider in the development of human resources is an increase in employee competence, improved careers, and increased business performance.

Dessler \& Huat (2019: 144) states this assessment center as an effective method of selecting and promoting employees; it is also emphasized by Prihadi that assessment center is not a place (building etc.), assessment refers more to processes and procedures for measuring competence.

In PT Kimia Farma (Persero) Tbk, the special space for assessment does not exist; but the company has 3 psychologists to map the talents, interests and potentials of the Company's employees at the downward level of assurance, to the top manager level, the Company uses the assessment center consultant services. The Company's business transformation, from the pharmaceutical industry to the healtcare company, brings new positions and positions. With the need for human resources to fill the position, it is necessary assessment effort for the candidates to be obtained according to the potential between themselves with the requirements of competence standards (SKJ).

\section{Employee Training Strategy}

The Company has provided training for all new employees who joined the company and continued into ongoing training. The Company's attention to employees in this form of training has been proved by the award of The Best Companies to Work For In Indonesia by HR Asia in 2016.

Sultana (2013: 576) states the training aims to improve employee competitiveness. This is in line with the training materials provided by the Company. The three generic competencies provided by the Company are leadership skills, business skills, and managerial skills, which then develop these generic competencies into training materials appropriate to each level of education. The transformation of the Company into the healtcare company industry requires human resources with competencies tailored to the needs of the industry. This healtcare industry, more nuances of service industries / services (services industry); which requires hospitality. Therefore, the training program created is based on a training needs analysis (TNA) analysis tailored to the demands of the healtcare industry as well as the competency gap. 


\section{E. Human Capital Development Strategy}

As a form of the Company's transformation program, PT Kimia Farma (Pereso) Tbk is very concerned in developing the human capital of the Company. This is reflected in the company's efforts to provide ongoing training and education. Ongoing training is reflected in tiered management training, while continuing education is realized in the form of full scholarship and part scholarship to employees to continue their studies from Diploma III to S3 at accredited B and A colleges, according to the interests and fields of each employee. strive for their level of education to be improved. Where one of the ways in which the Company covers this gap is to establish a pharmacy school in Bandung.

\section{CONCLUSION}

the human capital development strategy that has been conducted by the Company as follows. 1) The HR planning strategy has been developed based on the Company's HR development roadmap, tailored to the company's vision and mission, and then downgraded (casecade) into the vision and mission of the Human Capital Division; and has developed human resource requirements based on company business development such as plans for establishment of Banjaran factory, overseas pharmacy development, and establishment of hospitals \& hotels. 2) Recruitment and selection strategies undertaken by the Company by publicly announcing available job vacancies to internal and external candidates of candidates. As for the selection of prospective employees, the Company has conducted selection stages in accordance with SOP, starting from the selection of administrative files, initial interviews with Human Capital Division, presentation to directors, psychotest, medical test, internship, until PKWT work contract. 3) An assessment strategy undertaken by the Company to assess and measure the competence of its employees, whether for promotion or talent pool-by using the services of a professional assessment consultant for the manager level upwards, while for asman under assessment conducted by the psychologists of the Company. Although physically the Company does not have an assessment center yet, the assessment process has been under way for employee development and talent development of the Company's employees. 4) Training strategy. Training strategy undertaken by the Company by providing continuous tiered training on an ongoing basis, starting with executor level with basic management training as a prerequisite for promotion to the supervisor; young management training for supervisors as a prerequisite for upgrading to assistant manager level; middle management training, for assistant managers as a prerequisite for upgrading to manager level; main management training for managers, as a prerequisite for upgrading to general manager level; as well as the top management training provided to GM and the directors of subsidiaries. 5) Human capital development strategy. The company's human capital development strategy is to provide full scholarships and partial scholarships to permanent employees / PKWTTs. The Company also plans to 
establish a pharmacy school to address competency gaps and demands of Law no. 36 years 2014 About Health Workers. In addition, due to the considerable number of employees, which are 8,056 and spread throughout Indonesia, the Company has developed E-Learning-distance learning.e an impact on teacher performance.

\section{REFRENCES}

Anyadike, Nkechi O. "Human Resource Planning and Employee

ProductivityinNegeria Public Organization".Global Journal of Human Resource Management.Vol. 1 No. 4. December 2013.

Asfaw, Abeba M.,Argaw, Mesele D., \&Bayissa, Lemessa. "The Impact of Training and Development on Employee Performance and Effectiveness: A Case Study of District Five Administration Office, Bole Sub-City, Addis Ababa, Ethiopia." Journal of Human Resource and Sustainability Studies.

December 2015.

Daymon, Christine \& Holloway,Immy.Qualitative Research Methods in Public Relations and Marketing Communications. Second edition. New York: Routledge. 2011.

Dessler, Gary \&Huat, Tan C., Human Resource Management: An Asian Perspective. Second Editon. Singapore: Prentice Hall. 2009.

Ekwoaba, Joy O., Ikeije, Ugochukwu U. \&Ufoma, Ndubuisi. "The Impact of Recruitent and Selection Criteria on Organizational Perfomance."Global Journal of Human Resource Management. Vol. 3 No.2. March 2015.

Knapp, Paul R. \& Mujtaba, Bahaudin G. "Strategies for the Design and Administration of Assessment Center Technology: A Case Study for the Selection and Development of Employees." Journal of Business Studies. Vol. 2 No. 2. Quarterly 2011

Koltnerová,Kristína.,Chlpeková, Andrea.,\&Samáková, Jana."The Importance of Human Resource Planning in Industrial Enterprises."Research Papers Faculty of Materials Science and Technologi in Trnava. 2012.

Marimuthu, Maran.,Arokiasmy, Lawrence., \& Ismail, Maimunah. "Human Capital Development and Its Impact on Firm Performance: Evidence From Development Economic.'The Journal of International Social Research.Volume 2 /8.Summer 2009.

Muryanto, Edi. "Bersama Majukan Kimia Farma." GEMAKAEF. Edisi 39 Tahun 2015.

Nda, M. Muhammad \&Fard, R. Yazdani. "The Impact of Employee Training and Developemtn on Employee Productivity."Global Journal of Commerce \& Management Perspective.Vol. 2 (6). November-December 2013.

Noe, Raymond A. Human Resource Management: Gaining A Competitive Advantage. Seventh Edition. New York: McGraw Hill. 2010.

Prashanthi, K. "Human Resource Planning-An Analytical Study", International Journal of Business and Management Invention, Volume 2 Issue, January 
2013.

Prihadi, Syaiful F. Assessment Centre: Identifikasi, Pengukuran, danPengembanganKompetensi. Jakarta: GramediaPustakaUtama. 2004.

Raza, Hasan.,Anjum, Mehmood.\& Zia, Syed Muhammad. "The Impact of Employee's Job Performance Behavior and Organizational Culture on Organizational Productivity in Pharmaceutical Industry in Karachi," Interdisciplinary Journal of Contemporary Research Business, Vol .5 No. 12, April 2014.

Sampurno.“KapabilitasTeknologidanPenguatan R\&D: TantanganIndustriFarmasi Indonesia," MajalahFarmasi Indonesia, 18 (4), 2007.

Sekaran, Uma.Research Methods for Business: A Skill Building Approach.Fourth Edition. United States: John Wiley \& Son. 2003.

Sultana,Mahbuba. "Impact of Training in Pharmaceutical Industry: An Assessment on Square Pharmaceuticals Limited Bangladesh."International Journal of Science and Research (IJSR).Volume 2 Issue 2. February 2013.

Thornton III, George C., \& Gibbons, A. M. "Validation of Assessment Centers for Personnel Selection.”Human Resource Management Review. 19. 2009.

Yadav, Rajesh K. \&Dabhade, Nishant. "Human Resource Planning and Audit-a Case Study of HEG Limited”.International Letters of Social and Humanistic Sciences. Vol. 16, 2014.. 